\title{
The Impact of the Mathematics Support Centre on the Grades of First Year Students at the National University of Ireland Maynooth
}

\author{
Ciarán Mac an Bhaird, Tadhg Morgan ${ }^{1}$ and Ann O’Shea \\ Department of Mathematics, National University of Ireland Maynooth.
}

\begin{abstract}
In this paper we consider the mathematics grades of first year students at the National University of Ireland Maynooth and the influence that the Mathematics Support Centre has on these grades. We will consider evidence to suggest that the Mathematics Support Centre has a positive effect on the grades of the students who attend the centre. It seems to be particularly beneficial to students with weak mathematical backgrounds. As these students are most at risk of failing or dropping out of University, the positive impact of the Mathematics Support Centre on their grades is very encouraging.
\end{abstract}

\section{Introduction}

The Mathematics Support Centre (MSC) at the National University of Ireland Maynooth opened in October 2007. The centre operated as a drop-in facility, staffed by the manager (Ciarán Mac an Bhaird) and experienced tutors. The centre was open for 18 hours per week for 10 weeks in each semester. In semester 1, there were 1063 student visits to the centre and in semester 2 there were 1430 visits.

In the summer of 2008, we endeavoured to measure the effectiveness of the MSC. We did this in two ways: we studied the student feedback concerning the MSC [1]; we analysed the grades of students who had attended the MSC and compared them with the grades of students who had not attended. In this paper we will concentrate on the results of the second analysis, and in particular on the effect of the MSC on the grades of two groups of first year students.

In recent years, a number of studies concerning the impact of mathematics support centres on student achievement and retention have been published. Pell and Croft [2] consider first year Engineering students at Loughborough University. They estimated that the Mathematics Support Centre improved the pass rate of these students by about 3\%. Dowling and Nolan [3] looked at the pass rates of at-risk students at Dublin City University, and concluded that their Mathematics Learning Centre made a positive contribution to student retention. Patel and Little [4] had similar findings. Lee et al [5] found that the results of diagnostic tests and attendance at Mathematics Support Centres were significant predictors of end of year results. Croft has written a survey article [6] on the methods used to evaluate mathematics support and has created a webpage [7] with links to papers on this topic.

It should be noted at this stage that it is difficult to evaluate the performance of the MSC using students' Mathematics grades because so many factors affect performance on examinations. For example it is impossible to measure how much time students spent studying the subject. It is possible that students who attended the MSC centre did better in their exams than those who did not simply because these students worked harder. With this in mind, we will also consider performance on past examinations when comparing the grades of the students who attended the MSC with those who did not attend.

In particular, we will consider students' marks in mathematics in the Leaving Certificate (LC), a state examination taken in Ireland at the end of second level schooling that determines entry into third level. Most students (96\%) who take the Leaving Certificate study mathematics [8]. The

1 This author was supported by a National University of Ireland Maynooth Summer Programme for Undergraduate Research (SPUR) grant. 
subject can be studied at three different levels at LC: Foundation Level, which is taken by about $11 \%$ of students; Ordinary Level (OL), which is taken by about $71 \%$ of students; and Higher Level (HL) which is taken by about $18 \%$ of students. Students who study mathematics at Foundation Level are not eligible for admission into third level, so the students in our first year classes have either studied HL or OL mathematics.

We will also consider the scores of our first year students on a mathematics diagnostic test, which is administered in all mathematics classes in the first week of semester 1 . This test covers very basic material concerning algebra and algebraic manipulations as well as basic trigonometry and functions. Students with a score of 20 or less out of 60 on this test are offered extra tutorials. The scores from this test as well as the LC grades will help us get a picture of a student's mathematical background.

\section{Results}

\section{The Arts and Science Groups}

The two main first year groups taught by the Mathematics Department are the First Arts and Finance students, and the First Science students. The Arts students have chosen to study Mathematical Studies as one of their three subjects in their first year. About two thirds of these students end up studying mathematics to degree level. The Finance students are strongly encouraged to take the mathematics course, although they could opt to take another Arts subject instead. These students study mathematics for the first two years of their programme and they are taught in the same class as the Arts students, and make up about half the group. Every first year Science student must take mathematics as a compulsory subject. The majority of these students are in degree programmes like Biological Sciences or Pharmaceutical Chemistry. Less than ten percent of the First Science cohort will end up studying mathematics to degree level. In the analysis that follows we will treat the Arts and Finance students as one group (and call them First Arts). The courses that the Arts and Science students take are very similar, both in content and in standard. They all take two Calculus modules, a Linear Algebra module, and a Data Analysis module.

\begin{tabular}{|l|l|l|l|l|l|c|}
\hline Group & $\begin{array}{l}\text { Number } \\
\text { of } \\
\text { Students }\end{array}$ & $\begin{array}{l}\text { Percentage of } \\
\text { students who } \\
\text { visited MSC } \\
\text { more than } \\
\text { once }\end{array}$ & $\begin{array}{l}\text { Pass rate of } \\
\text { students } \\
\text { who visited } \\
\text { MSC more } \\
\text { than once }\end{array}$ & $\begin{array}{l}\text { Pass rate of } \\
\text { students } \\
\text { who visited } \\
\text { MSC once } \\
\text { or less }\end{array}$ & $\begin{array}{l}\text { Mean Final } \\
\text { Mark out of } \\
1000 \text { of } \\
\text { students who } \\
\text { visited MSC } \\
\text { more } \\
\text { once }\end{array}$ & $\begin{array}{l}\text { Mean Final } \\
\text { Mark out of } \\
\text { than } \\
\text { tondudents who } \\
\text { visited MSC } \\
\text { once or less }\end{array}$ \\
\hline $\begin{array}{l}\text { First } \\
\text { Arts }\end{array}$ & 201 & $28 \%$ & $89 \%$ & $62 \%$ & 565 & 499 \\
\hline $\begin{array}{l}\text { First } \\
\text { Science }\end{array}$ & 254 & $22 \%$ & $71 \%$ & $65 \%$ & 509 & 488 \\
\hline
\end{tabular}

Table 1: Mathematics Grades of all First Year Students

We will compare the performance of students who attended the MSC more than once and those who attended once or less. We will assume that students who attended the MSC once only did not receive enough assistance to significantly affect their grade. It can be seen from Table 1 that for Arts students there is a significant difference between the pass rates of students who attended the MSC more than once (89\%) and those who did not (62\%). This difference is statistically significant (chisquared test, $\mathrm{p}<0.001$ ). If we consider the mean final subject mark for Arts students, we see that there is a significant difference between the mean mark of those who attended the MSC more than once and those who did not, (t-test, $\mathrm{p}=0.023$ ). A 95\% confidence interval for the difference of the means is $(9.416,123.25)$. The final subject marks are scored out of 1000 and are the weighted 
average of the four module marks. The situation is a little less clear for Science students. Although the pass rate and mean final marks for students who attended the MSC more than once are higher than those of the students who did not, these differences are not statistically significant.

\section{Using Leaving Certificate Results}

As mentioned previously, it is difficult to conclude from the results above alone that the MSC has an effect on students' grades. For example, it may be that only the very best students use the service and that is why the grades are different. Therefore, it seems sensible take the students' Leaving Certificate grades in mathematics into consideration. Tables 2 and 3 show that if we break the group down by Leaving Certificate grade then the mean mark of the students who attended is always higher than the mean mark of those who did not. Note that Leaving Certificate grades are not available for all students, as many foreign and mature students have not taken the examination.

\begin{tabular}{|l|l|l|l|l|}
\hline Group & $\begin{array}{l}\text { Mean Mark of } \\
\text { students who } \\
\text { visited more } \\
\text { than once }\end{array}$ & $\begin{array}{l}\text { Number of } \\
\text { Students }\end{array}$ & $\begin{array}{l}\text { Mean Mark of } \\
\text { students who } \\
\text { visited once or } \\
\text { less }\end{array}$ & $\begin{array}{l}\text { Number of } \\
\text { Students }\end{array}$ \\
\hline HA & - & 0 & 723.20 & 5 \\
\hline HB & 720.63 & 8 & 671.42 & 19 \\
\hline HC & 608.33 & 6 & 565.20 & 35 \\
\hline HD & 536.00 & 5 & 448.58 & 12 \\
\hline OA & 540.86 & 21 & 451.25 & 40 \\
\hline OB & 473.56 & 9 & 313.62 & 26 \\
\hline OC & 480.00 & 1 & 342.00 & 1 \\
\hline OD & - & 0 & 157.00 & 1 \\
\hline
\end{tabular}

Table 2: Comparison of Mathematics Final Marks for First Arts and Finance by LC Grade

\begin{tabular}{|l|l|l|l|l|}
\hline Group & $\begin{array}{l}\text { Mean Mark of } \\
\text { students who } \\
\text { visited more } \\
\text { than once }\end{array}$ & $\begin{array}{l}\text { Number of } \\
\text { Students }\end{array}$ & $\begin{array}{l}\text { Mean Mark of } \\
\text { students who } \\
\text { visited once or } \\
\text { less }\end{array}$ & $\begin{array}{l}\text { Number of } \\
\text { Students }\end{array}$ \\
\hline HA & - & 0 & 761.00 & 5 \\
\hline HB & 752.25 & 4 & 730.92 & 25 \\
\hline HC & 719.75 & 4 & 635.64 & 28 \\
\hline HD & 654.00 & 1 & 567.47 & 17 \\
\hline OA & 547.56 & 9 & 511.84 & 37 \\
\hline OB & 450.00 & 19 & 381.86 & 36 \\
\hline OC & 320.00 & 5 & 288.87 & 15 \\
\hline OD & 510.00 & 1 & 302.17 & 6 \\
\hline
\end{tabular}

Table 3: Comparison of Mathematics Final Marks for First Science by LC Grade

If we look only at students who studied Mathematics at Ordinary Level (OL) at Leaving Certificate, we see from Table 4 that for Arts students there is a significant difference between the pass rate of the students who attended the MSC more than once (84\%) and that of those that did not (38\%), (chi-squared test, $\mathrm{p}<0.001$ ). Once again the difference for Science students is not statistically 
significant, even though the pass rate of students who attended the MSC more than once (64\%) is higher than the pass rate of those who did not (53\%). If we consider the mean final marks of students, we see that for the Arts students there is a significant difference in the marks of the two groups of students (t-test, $\mathrm{p}<0.001$ ), a 95\% confidence interval for the difference in means is (65.243, 198.749). Once again, the mean mark for the Science students who attended the MSC more than once is bigger than the mean mark of the group who did not, but the difference is not statistically significant. If we consider the HL students in Arts and divide the group into those who attended the MSC more than once and those who did not, there is some evidence of a difference in pass rates (Fisher exact test, $\mathrm{p}=0.062$ ). In fact, the pass rate for HL students who attended more than once was $100 \%$, compared to $82 \%$ for the other group.

\begin{tabular}{|c|c|c|c|c|c|c|}
\hline Group & $\begin{array}{l}\text { Number } \\
\text { of } \\
\text { Students }\end{array}$ & $\begin{array}{l}\text { Percentage of } \\
\text { students who } \\
\text { visited MSC } \\
\text { more than } \\
\text { once }\end{array}$ & $\begin{array}{l}\text { Pass rate of } \\
\text { students } \\
\text { who visited } \\
\text { MSC more } \\
\text { than once }\end{array}$ & $\begin{array}{l}\text { Pass rate of } \\
\text { students } \\
\text { who visited } \\
\text { MSC once } \\
\text { or less }\end{array}$ & $\begin{array}{lr}\text { Mean } & \text { Final } \\
\text { Mark (out of } \\
1000 \text { ) } \\
\text { students }\end{array}$ & $\begin{array}{l}\text { Mean Final } \\
\text { Mark (out of } \\
1000 \text { ) of } \\
\text { students who } \\
\text { visited MSC } \\
\text { once or less }\end{array}$ \\
\hline $\begin{array}{l}\text { First } \\
\text { Arts }\end{array}$ & 100 & $32 \%$ & $84 \%$ & $38 \%$ & 525 & 393 \\
\hline $\begin{array}{l}\text { First } \\
\text { Science }\end{array}$ & 136 & $26 \%$ & $64 \%$ & $53 \%$ & 445 & 403 \\
\hline
\end{tabular}

Table 4: Mathematics Grades of Ordinary Level Students

\section{Using Diagnostic Test Results}

We will now look at the group of students who scored 20 or less on the diagnostic test. These students are considered by the department to be at-risk, and are offered extra help and extra tutorials to try to plug the gaps in their knowledge.

\begin{tabular}{|l|l|l|l|l|l|c|}
\hline Group & $\begin{array}{l}\text { Number } \\
\text { of } \\
\text { Students }\end{array}$ & $\begin{array}{l}\text { Percentage of } \\
\text { students who } \\
\text { visited MSC } \\
\text { more than } \\
\text { once }\end{array}$ & $\begin{array}{l}\text { Pass rate of } \\
\text { students } \\
\text { who visited } \\
\text { MSC more } \\
\text { than once }\end{array}$ & $\begin{array}{l}\text { Pass rate of } \\
\text { students } \\
\text { who visited } \\
\text { MSC once } \\
\text { or less }\end{array}$ & $\begin{array}{l}\text { Mean Final } \\
\text { Mark out of } \\
\text { 1000) of } \\
\text { students who } \\
\text { visited } \begin{array}{l}\text { Mean Final } \\
\text { more } \\
\text { mark out of } \\
\text { once }\end{array}\end{array}$ & $\begin{array}{l}\text { 1000) of } \\
\text { thadents who } \\
\text { visited MSC } \\
\text { once or less }\end{array}$ \\
\hline $\begin{array}{l}\text { First } \\
\text { Arts }\end{array}$ & 31 & $52 \%$ & $81 \%$ & $53 \%$ & 525 & 483 \\
\hline $\begin{array}{l}\text { First } \\
\text { Science }\end{array}$ & 78 & $33 \%$ & $73 \%$ & $46 \%$ & 481 & 362 \\
\hline
\end{tabular}

Table 5: Mathematics Grades of Students who scored 20 or less on a Diagnostic Test

Once again we see from Table 5 that for both groups of students the pass rate of students who used the MSC is better than the pass rate of those who did not use the service. In this case, the difference is not statistically significant for the Arts students (Fisher exact test, $\mathrm{p}=0.135$ ), possibly because the number of students in each category is so small. However the difference is statistically significant for the Science group (chi-squared test, $\mathrm{p}=0.024$ ). There is also a significant difference in the means of the final marks for the Science students (t-test, $\mathrm{p}=0.002$ ), a 95\% confidence interval for the difference in the means is $(46.15,193)$. 


\section{Conclusion}

It is very difficult to make any sweeping statements about the impact of the MSC on students' results based solely on the facts and figures from one year of operation. However, there is significant evidence to suggest that it is making a difference to the grades of the first year students who attend. We have seen that if we take Leaving Certificate or diagnostic test results as a measure of students' mathematical background then the MSC appears to have a particular influence on the most at-risk students.

It is interesting to note that the Arts students are more likely to attend the centre than the Science students, and in fact the Arts students visit more often. If we only consider the students who have attended the MSC, then the median number of visits for the Arts students is 5 and for the Science students is 3. This might be a result of the fact that the Arts students have chosen to study mathematics whereas for the Science students mathematics is a compulsory subject. The higher levels of attendance by Arts students may reflect their interest in the subject. The difference was more pronounced for later years. More than two thirds of second and third year Arts students attended the MSC as opposed to about one third of the second and third year Science students. In the case of the first year students, the at-risk students were more likely to attend than the students with stronger mathematical backgrounds, and seemed to be using the centre to improve their chances of passing the exam. In contrast it was the strong students in Second and Third Arts who were more likely to attend and these students seemed not to be worried about failing but were using the centre to improve their chances of achieving a first class mark. This bears similarities to the situation described in [2].

It is noticeable also that the majority of the at-risk students did not attend the MSC. This is more pronounced in the case of the Science students where only $26 \%$ of the Ordinary level students and only $33 \%$ of the students who had scored 20 or less on the diagnostic test attended the centre more than once. It seems likely, from our analysis, that the MSC could have helped more of these students to pass the exams if they had attended. Targeting these students in the future must be a priority for the centre.

It must be stated that visiting the MSC alone is not sufficient to improve grades, the students must be willing to work independently, but as seen in [1], attendance at the centre boosts student confidence. It also encourages the students to work on mathematics regularly throughout the year, and this is another important factor when considering the end of year grades.

\section{References}

1. Mac an Bhaird, C., Morgan, T, O’Shea, A., (2009) Evaluating the impact of mathematics support on students' attitudes to mathematics in the National University of Ireland, Maynooth, (preprint).

2. Pell, G., Croft, T., (2008) Mathematics support - support for all?, Teaching Mathematics and its Applications, 27, 167-173.

3. Dowling, D., Nolan, B., (2006) Measuring the effectiveness of a maths learning centre - The Dublin City University experience, Proceedings of the CETL MSOR Conference 2006. Publ. MSOR Network. 51-54.

4. $\quad$ Patel, C., Little, J., (2006) Measuring maths study support, Teaching Mathematics and its Applications, 25, No. 3, 131-138.

5. Lee, S., Harrison, M., Pell, P., Robinson, C., (2008) Predicting performance of first year engineering students and the importance of assessment tools therein, Engineering Education, 3, 44-51.

6. Croft, T., (2008) Towards a culture of data collection an analysis in mathematics support 
centres, Presented at the $3^{\text {rd }}$ Irish Workshop on Mathematics Learning and Support Centres, NUI Maynooth, December 2008. http://www.ndlr.ie/mshe/?p=21, accessed January 2009.

7. Croft, T., available at

http://www.mathcentre.ac.uk/staff.php/all_subjects/measuring_effectiveness/resources.

8. Department of Education and Science, (2005), Annual Statistical Report 2003/2004, Government Stationary Office, Dublin. 